\title{
Five new genera of Baetidae (Insecta : Ephemeroptera) from South America
}

\author{
C.R. Lugo-Ortiz 1 \\ W.P. McCafferty ${ }^{1}$
}

Keywords : Ephemeroptera, Baetidae, South America, Cryptonympha, Rivudiva, Spiritiops, Varipes, Zelusia, new genera, new species.

The description of new taxa of small minnow mayflies (Insecta : Ephemeroptera : Baetidae) includes the following. Cryptonympha copiosa $\mathbf{n}$. gen. and $\mathbf{n} . \mathbf{s p}$., from Brazil, is distinguished by long, robust, pilose setae on the medial margin of the prosthecae ; apically narrow glossae and paraglossae ; absence of hindwingpads ; and long, basally narrow gill 1. Rivudiva $\mathrm{n}$. gen., including $R$. minantenna $\mathrm{n}$.sp., from Brazil, and $R$. trichobasis n.sp., from Brazil and Paraguay, is distinguished by a broad lingua and relatively narrow superlinguae ; broad glossae with a distomedial row of long, robust, falcate, simple setae ; and tarsal claws with minute denticles arranged in an ellipse. Spiritiops silvudus n.gen. and n. sp., from Brazil and French Guyana, is distinguished by a long, robust, pilose seta arising from the medial margin of the right prostheca and tarsal claws with two rows of denticles and lateral long, fine, simple seta. Varipes lasiobrachius n. gen. and n. sp., from Colombia and Ecuador, is distinguished by the reduced right prostheca and U-shape arrangement of denticles on the tarsal claws. Zelusia principalis $\mathrm{n}$. gen. and $\mathrm{n}$. sp., from Brazil and Colombia, is distinguished by a medially raised labrum, bifid right prostheca, and long, slender maxillary palps.

\section{Cinq genres nouveaux de Baetidae (Insecta : Ephemeroptera) d'Amérique du Sud}

Mots clés : Ephemeroptera, Baetidae, Amérique du Sud, Cryptonympha, Rivudiva, Spiritiops, Varipes, Zelusia, genres nouveaux, espèces nouvelles.

De nouveaux taxons d'Ephémères Pisciforma (Insecta : Ephemeroptera : Baetidae) sont décrits ci-après. Cryptonympha copiosa n. gen. et n. sp., du Brésil, se distingue par des soies longues, robustes et barbelées sur le bord médian des prosthecae ; par des glosses et paraglosses étroites à l'apex ; par l'absence de fourreaux alaires postérieurs ; et par la branchie 1 longue, étroite à la base. Rivudiva n. gen., incluant $R$. minantenna n. sp., du Brésil, et $R$. trichobasis $\mathrm{n}$. sp., du Brésil et du Paraguay, se distingue par une large lingua et des superlinguae relativement étroites ; par de larges glosses avec une rangée médiodistale de soies longues, robustes, falciformes, et simples ; et par des griffes tarsales avec de minuscules denticules disposés en ellipse. Spiritiops silvudus n. gen. et n. sp., du Brésil et de la Guyane Française, se distingue par une longue et robuste soie barbelée implantée sur le bord médian de la prostheca droite, et par des griffes tarsales portant deux rangées de denticules et une longue soie latérale simple et fine. Varipes lasiobrachius n. gen. et n. sp., de Colombie et de l'Equateur, se distingue par la prostheca droite réduite et par la disposition en $U$ des denticules des griffes tarsales. Zelusia principalis $\mathbf{n}$. gen. et $\mathbf{n}$. sp., du Brésil et de Colombie, se distingue par un labre convexe dans la région médiane, par une prostheca droite bifide, et par des palpes maxillaires longs et minces.

\section{Introduction}

The faunal composition of the family Baetidae (Ephemeroptera) in South America historically has been poorly documented but recently has received

1. Department of Entomology, Purdue University, West Lafayette, IN 47907, USA. considerable attention (see, e.g., Lugo-Ortiz \& McCafferty 1995, 1996abcd, 1997ab). We can account for 14 baetid genera on the continent : Adebrotus Lugo-Ortiz \& McCafferty, Americabaetis Kluge, Aturbina LugoOrtiz \& McCafferty, Baetodes Needham \& Murphy, Bernerius Waltz \& McCafferty, Callibaetis Eaton, $\mathrm{Ca}$ melobaetidius Demoulin, Cloeodes Traver, Guajirolus Flowers, Harpagobaetis Mol, Mayobaetis Waltz \& McCafferty, Moribaetis Waltz \& McCafferty, Prebae- 
todes Lugo-Ortiz \& McCafferty, Tomedontus LugoOrtiz \& McCafferty, and Waltzoyphius McCafferty \& Lugo-Ortiz. The generic names Baetis Leach, Cloeon Leach, and Pseudocloeon Klapálek have been applied to several South American species, but predictably neither Baetis or Cloeon occur in South American based on broad phylogentic biogeographic analyses (McCafferty et al. 1992, McCafferty, in manuscript). The concept of Pseudocloeon has been restricted to the Oriental type species, $P$. kraepelini Klapálek (Waltz \& McCafferty 1985). The number of baetid genera in South America contrasts with the 20 genera reported from North america north of Mexico (McCafferty \& Waltz 1990, McCafferty 1996). This is clearly an underestimation based on our current studies of the Neotropical Ephemeroptera fauna, and would have been surmised simply on the basis of the abundance and heterogeneity of freshwater habitats in South America (Lewis et al. 1995).

We herein describe five new genera and six new species of Baetidae from South America. All new taxa are described from larvae only. Although it is ideal to describe new taxa based on both larval and adult material, it is often not practical nor prudent. Lugo-Ortiz \& McCafferty (1996c) pointed out the expediency and rationale for describing taxa based on the aquatic, and most readily accessible, larval stage in view of impending and current freshwater habitat degradation and deforestation in the Neotropics (see, e.g., Myers 1997). Our view remains that the importance of documenting biodiversity at risk overrides any taxonomic idealism. The material examined is housed in the Purdue Entomological Research Collection, West Lafayette, Indiana, except where indicated otherwise.

\section{Cryptonympha Lugo-Ortiz \& McCaffer- ty n. gen.}

«Genus 2 nr. Pseudocloeon Klapalek» Roback 1966 : 135

\subsection{Description}

Larva

- HEAD

Frontal keel absent. Antennae with scapes as long as pedicels.

Labrum (Fig. 1) narrowly rounded anteriorly, with deep anteromedian emargination.

Hypopharynx (Fig. 2) with broad lingua and superlinguae.

Mandibles (Figs. 3,4) with incisors fused, denticles distinct ; prostheca of left mandible robust, apically denticulate, with long, robust, pilose seta arising distomedially ; prostheca of right mandible apically acute, with long, robust, pilose seta arising distomedially; right mandible with tufts of long, fine, simple setae between prostheca and mola and base of mola.

Maxillae (Fig. 5) with two-segmented palps, slightly extending beyond galealaciniae ; crown of galealaciniae with four denticles.

Labium (Fig. 6) with glossae as long as paraglossae ; glossae apically narrow ; paraglossae apically narrow, nearly $3.3 \mathrm{x}$ longer than wide ; palp segment 1 as long as segments 2 and 3 combined; palp segment 2 with thumblike distomedial process ; palp segment 3 conical.

\section{- THORAX}

Femora (Fig. 7) broad, without villopore ; tarsal claws (Fig. 8) with single row of denticles.

\section{- ABDOMEN}

Terga (Fig. 9) with scales, scale bases, and posterior marginal spines.

Gills (Figs. 10, 11) on abdominal segments 1-7, poorly serrate at margins (Fig. 12) ; gill 1 nearly $2.5 \mathrm{x}$ length of segment 1 , narrowly based.

Paraprocts (Fig. 13) with marginal spines.

Terminal filament as long as cerci.

\section{Adult}

Unknown.

\subsection{Type species}

Cryptonympha copiosa Lugo-Ortiz \& McCafferty, n. sp.

\subsection{Included species}

Cryptonympha copiosa Lugo-Ortiz \& McCafferty, n. sp. (larva).

\subsection{Distribution}

Brazil (Acre, Amazonas, Pará, Rio Grande do Sul, Santa Catarina), Peru.

\subsection{Etymology}

The generic name is an arbitrary combination of letters, but incorporates the Greek words kryptos (hidden) and nymphe (goddess of springs and rivers). The gender is feminine.

\subsection{Discussion}

Larvae of Cryptonympha are distinguished by the long, robust, pilose setae on the medial margin of the prosthecae (Figs. 3, 4) ; apically narrow glossae and 

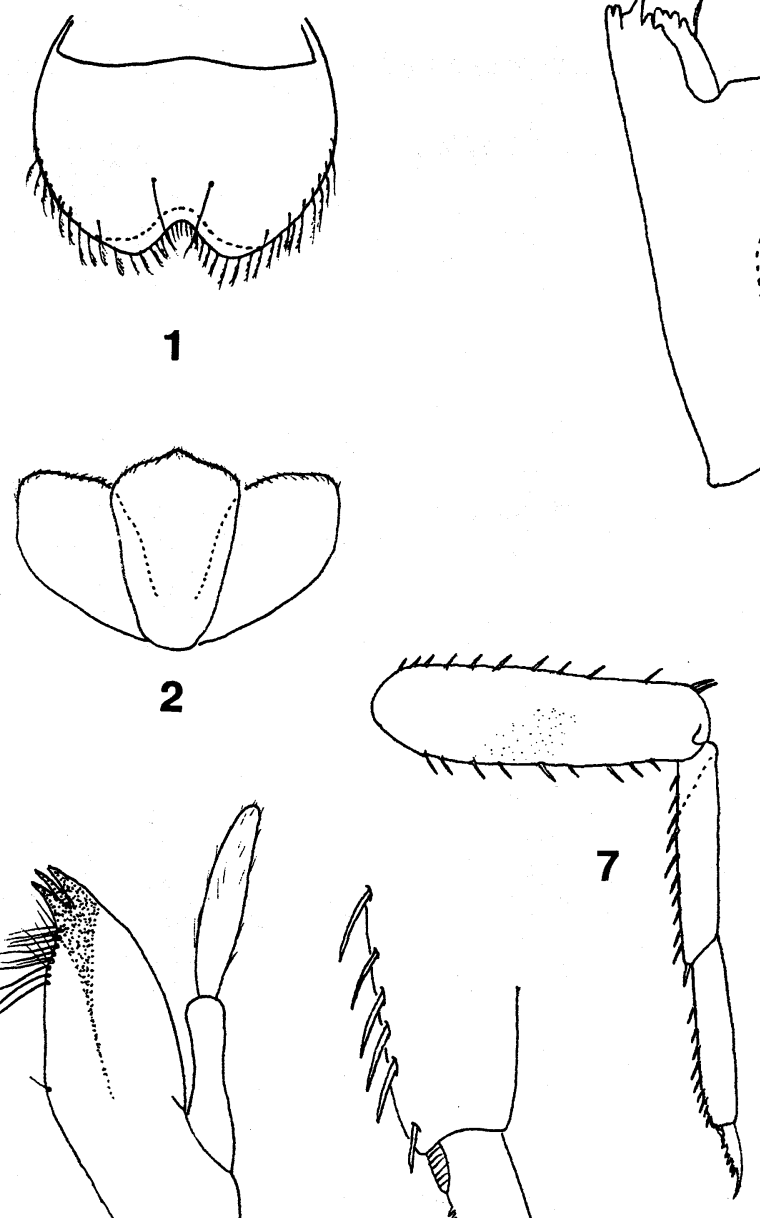

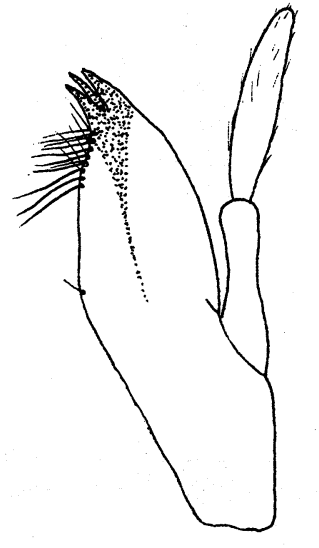

5

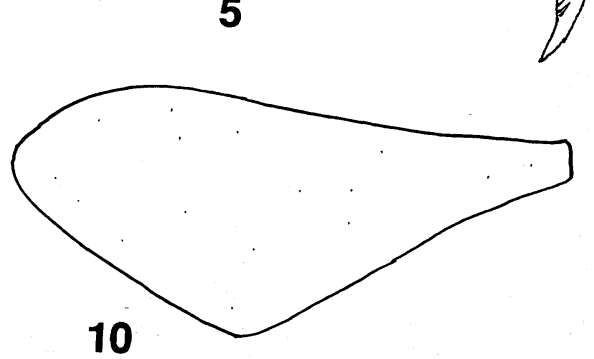

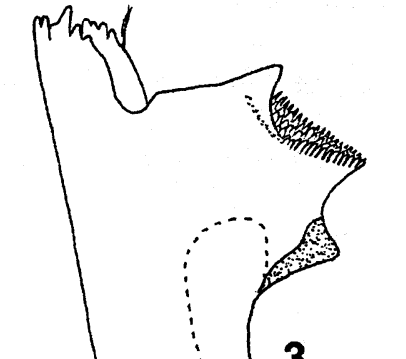
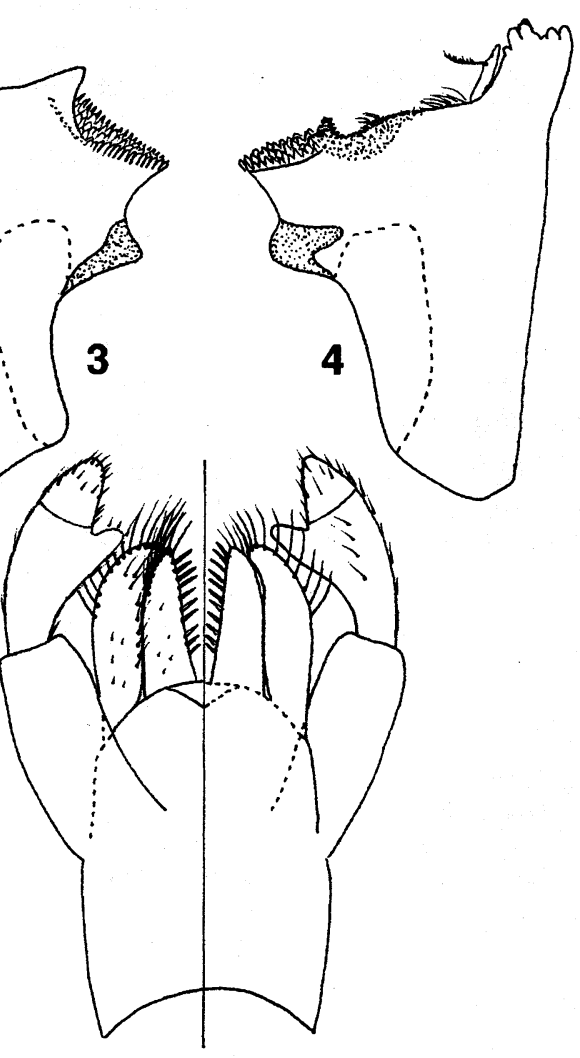

6
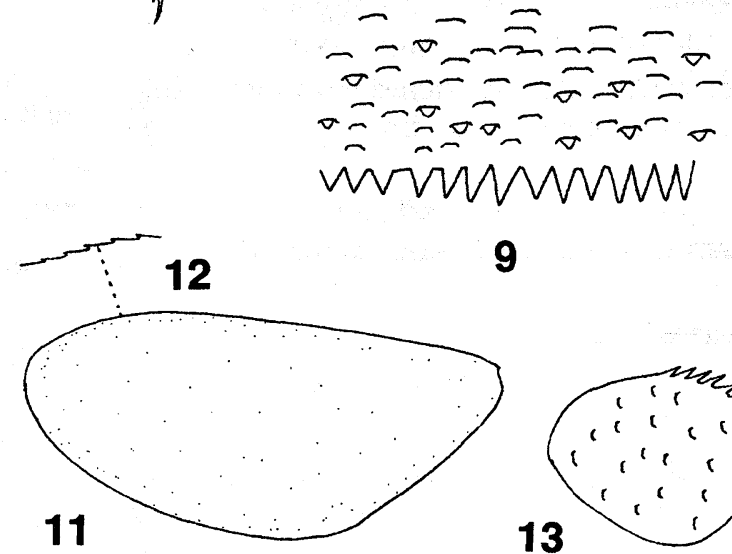

9

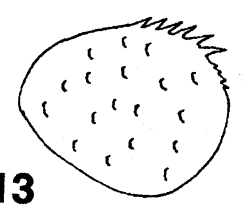

Figs. 1 to 13. Larval structures of Cryptonympha copiosa. 1 : labrum (dorsal). 2 : hypopharynx. $3:$ left mandible. $4:$ right mandible. $5:$ right maxilla. 6 : labium (left-ventral ; right dorsal). $7:$ left foreleg. $8:$ tarsal claw. $9:$ tergum 4 (detail). $10:$ gill $1.11:$ gill 4 . $12:$ gill 4 (detail of margin). 13 : paraproct.

Figs. 1 à 13. Structures larvaires de Cryptonympha copiosa. $1:$ labre (vue dorsale). $2:$ hypopharynx. $3:$ mandibule gauche. $4:$ mandibule droite. $5:$ maxille droite. $6:$ labium (à gauche-vue ventrale ; à droite-vue dorsale). $7:$ patte antérieure gauche. $8:$ griffe tarsale. $9:$ détail de la surface du $4^{\mathrm{e}}$ tergite. $10: 1^{\mathrm{e}}$ branchie. $11: 4^{\mathrm{e}}$ branchie. $12:$ détail du bord de la $4^{\mathrm{e}}$ branchie. $13:$ paraprocte. 
paraglossae (Fig. 6) ; absence of hindwingpads ; and long, basally narrow gill 1 (Fig. 10).

Larvae of Cryptonympha might be possibly confused with those of Americabaetis. Larvae of Americabaetis, however, lack medial setae on the prosthecae (Lugo-Ortiz \& McCafferty 1997b : Figs. 2, 3, 18, 19, $28,29,37,38,47,48)$, have apically broad glossae and paraglossae (Lugo-Ortiz \& McCafferty 1997b : Figs. $6,21,31,40,50$ ), and gills are present on segments 2 7 only. Eventually, the two genera may be shown to be related, if the general morphology of segment 2 of the labial palps proves synapomorphic.

Roback (1966) briefly described larvae collected from the Nanay River in the Loreto Province of Peru as «Genus 2 nr. Pseudocloeon Klapalek». His description and figures (Roback 1966 : Figs. 59-63) agree with our concept of Cryptonympha, and we therefore assign those larvae to the genus. However, we were not able to secure Roback's specimens for examination, and we therefore could not ascertain whether they represent a different species from the new species described below.

\subsection{Cryptonympha copiosa Lugo-Ortiz \& McCaf- ferty, n. sp.}

\subsubsection{Description}

Larva

Body length : 4.3-5.5 mm ; caudal filaments length : 1.8-2.3 mm.

\section{- HEAD}

Coloration yellow-brown to medium brown, generally with vermiform markings on frons and vertex.

Antennae nearly $2.5 x$ length of head capsule; scapes and pedicels with minute, fine, simple setae scattered over surface.

Labrum (Fig. 1) dorsally with submedial pair of setae and numerous long, branched setae on anterior margin.

Hypopharynx as in Figure 2.

Left mandible (Fig. 3) with $2+3$ denticles.

Right mandible (Fig. 4) with $3+3$ denticles.

Maxillae (Fig. 5) with palps with short, fine, simple setae scattered over surface ; segment 1 subequal in length to segment 2 ; short, fine, simple seta present on medial hump.

Labium (Fig. 6) with glossae with few short, fine, simple setae scattered over ventral surface, 10-12 long, relatively robust, simple setae medially, and numerous long, relatively robust, simple setae distally ; paraglossae with apical row of long, fine, simple setae ; palp segment 1 bare ; palp segments 2 and 3 with short, fine, simple setae scattered over surface; palp segment 2 with dorsal row of three to four long, fine, simple setae.

\section{- THORAX}

Coloration pale to medium yellow-brown, with no distinct color pattern. Hindwingpads absent.

Legs (Fig. 7) pale yellow-brown ; femora generally with light brown marking on anterior face, dorsally with row of 8-11 long, robust, simple setae, ventrally with row of 8-10 long, robust, simple setae ; tibiae dorsally with minute, fine, simple setae, ventrally with row of 8-11 long, robust, simple setae ; tarsi dorsally with minute, fine, simple setae, ventrally with $8-11$ robust, simple setae increasing in length distally ; tarsal claws (Fig. 8) with 14-16 sharp denticles, increasing in length distally.

\section{- ABDOMEN}

Coloration pale to dark yellow-brown ; tergum 1 uniformly pale to dark yellow-brown; terga $2-7$ pale to dark yellow brown, with faint anterolateral and posteromedial spots ; terga 8-10 generally uniformly pale yellow-brown.

Terga (Fig. 9) with posterior triangular marginal spines nearly $1.5 \mathrm{x}$ basal width length.

Gills (Fig. 10,11) poorly to relatively well tracheated ; gill $12.5 x$ length of corresponding segment ; middle gills $2.0 \mathrm{x}$ length of corresponding segments.

Paraprocts (Fig. 13) marginally with five to six long, acute spines and three to four short, relatively broad spines ; scale bases scattered over surface.

Caudal filaments cream to pale yellow-brown, generally with faint medium brown band in midregion.

\section{Adult}

\section{Unknown.}

\subsubsection{Material examined}

Holotype : Larva, Brazil, Acre State, Territorio Federal do Rio Branco, Cachangá Cr, 16-IX-1941, H. Sioli. Paratypes : Larva, Brazil, Amazonas State, Rio Negro at Içana, 25-IX1952, H. Sioli ; three larvae, Brazil, Pará State, Irurá Cr, Santarèm, 2-VII-1946, H. Sioli (one larva deposited in the entomological collection of the Instituto-Fundación Miguel Lillo, Tucumán, Argentina) ; larva, Brazil, Pará State, Paraná do Tapará, 15-VII-1946, H. Sioli ; larva, Brazil, Pará State, Urubú Cr, 24-XI-1952, H. Sioli. Additional material : Brazil : Acre State : Two larvae, same data as holotype. Amazonas State : Three larvae, mouth of Rio Uaupés, 15-IX-1952, H. Sioli ; larva, Anakaté Cr, 24-X-1959, H. Sioli and W. Sattler ; larva, Cachoeira Cr, nr Rio Cuieiras, $\mathrm{N}$ of Manaus, 15-XII1960, E.J. Fittkau ; same data, except two larvae, 17-XII1960 ; same data, except three larvae, 27-XI-1962 ; Cachoei- 
ra do Traira $\mathrm{Cr}$, waterfalls, $\mathrm{nr}$ Rio Cuieiras, $\mathrm{N}$ of Manaus, 16XII-1960, E.J. Fittkau ; 17 larvae, Cachoeira Cr, nr Acapamento, N of Manaus, 18-IV-1961, E.J. Fittkau ; larva, Gigante $\mathrm{Cr}$, rapids, Reserva Duke, N of Manaus, 3-VII-1961, E.J. Fittkau ; larva, Barro Branco Cr, Reserva Duke, $\mathrm{N}$ of Manaus, 3-XII-1960, E.J. Fittkau ; same data, except three larvae, 8-V-1961; same data, except six larvae, 16-V-1961; Rio Negro, at ject with cold water stream, Manaus, 14-XII-1960, E.J. Fittkau ; two larvae, Acara Cr, Reserva Duke, $\mathrm{N}$ of Manaus, 26-VI-1961, E.J. Fittkau ; five larvae, Cachoeira Cr, Indios Rapids, nr Rio Cuieiras, N of Manaus, 18-19-XII-1961, E.J. Fittkau ; 75 larvae, Aracu Cr, 15 km from Manaus, rd nr Rio Branco, 8-VI-1962, E.J. Fittkau ; two larvae, Pará Comiche rapids, $3 \mathrm{~d}$ trip above Santo Antônio Mission, NW of Taparuquara, 28-I-1963, E.J. Fittkau. Pará State : Larva, Rio Cururú, nr Mission, 31-III-1941, H. Sioli ; nine larvae, swift creek at Cururú Mission, 6-IV-1942, H. Sioli ; two larvae, Kenebiit-taibiri, 1-V-1942, H. Sioli ; two larvae, Rio Cururú, Mission, 12-V-1942, H. Sioli ; 13 larvae, Rio Erererí, Uisarang, 16-VI-1942,H. Sioli ; 60 larvae, Irurá Cr, Santarém, 2VII-1946, H. Sioli ; larva, Paraná do Tapará, 15-VII-1946, H. Sioli ; two larvae, Arraia Dam, 20-XI-1946, H. Sioli ; larva, Irurá Cr, 25-VI-1947, H. Sioli ; same data, except eight larvae, 10-VII-1947 ; five larvae, Grando do Jurucui Cr, 27-XI1947, H. Sioli ; larva, Paraná de Alemquer, 21-VIII-1949, H. Sioli ; two larvae, Rio Aruã, above rapids, 29-V-1952, H. Sioli ; larva, Rio Negro in Içana, 25-IX-1952, H. Sioli ; larva, same data, except 13-XII-1959, H. Sioli and W. Stattler ; six larvae, Mentai Cr, nr mouth, 12-XI-1952, H. Sioli ; four larvae, Urubú Cr, 24-XI-1952, H. Sioli ; three larvae, Guarimã Cr, 12-VIII-1953, H. Sioli ; three larvae, Aterro Cr, 21.6 km from Bragança, 14-XI-1953, H. Sioli ; larva, Rio Guamá, Ourém, 15-XI-1953, H. Sioli ; larva, swift creek, CururúMission, 1-II-1960, H. Sioli ; three larvae, Rio Cururú, Cururú Mission, 4-II-1961, E.J. Fittkau ; two larvae, Rio Paru, nr Tiriyos Mission, nr Brazil-Suriname border, 31-III-1963, E.J. Fittkau. Paraná State : Two larvae, Rio São Luis, $25^{\circ} 28^{\prime} \mathrm{S} / 49^{\circ} 45^{\prime} \mathrm{W}, 1000 \mathrm{~m}, \mathrm{~V}-1964$, F. Plaumann. Rio Grande do Sul State : Larva, Arroio Lageado, 2940'S, 55 33'W, $80 \mathrm{~m}$, XI-1964, F. Plaumann. Santa Catarina State : Two larvae, Rio Jacutinga, $27^{\circ} 06^{\prime} \mathrm{S} / 51^{\circ} 36^{\prime} \mathrm{W}$, IV-1962, F. Plaumann ; larva, Rio Warnow, $26^{\circ} 57^{\prime} \mathrm{S} / 48^{\circ} 17^{\prime} \mathrm{W}, 70 \mathrm{~m}$, XI1965, F. Plaumann.

\subsubsection{Etymology}

The specific epithet is a Latin adjective meaning abundant. It is in reference to the relatively widespread distribution and abundant samples.

\subsubsection{Discussion}

Although no comparative species of the genus are known, we expect that the presence of a submedial pair of setae dorsally on the labrum (Fig. 1), general mandibular denticulation (Figs. 3, 4), absence of hindwingpads, tarsal claws denticulation (Fig. 8), relatively long spines on the posterior margin of the abdominal terga (Fig. 9), and arrangement of paraproctal marginal spines (Fig. 13) may prove to be of importance for specific diagnosis.

\section{Rivudiva Lugo-Ortiz \& McCafferty, n. gen.}

\subsection{Description}

Larva

- HEAD

Frontal keel absent.

Antennae with pedicels subequal to (Fig. 14) or shorter than (Fig. 28) scapes.

Labrum subrectangular, with variable anteromedian emargination (Figs. 15, 29).

Hypopharynx (Figs. 16, 30) with broad lingua and relatively small superlinguae.

Mandibles (Figs. 17, 18) with incisors deeply cleft ; outer set of incisors of left mandible with four denticles, inner set with one denticle ; outer set of incisors of right mandible with three denticles, inner set with two poorly defined denticles ; prostheca of left mandible reduced to long, robust, single seta ; prostheca of right mandible bifid.

Maxillae (Fig. 19) with two-segmented palps, extending beyond galealaciniae ; crown of galealaciniae with four denticles.

Labium (Fig. 20) with glossae as long as paraglossae ; glossae (Fig. 21) with distomedial row of long, robust, falcate, simple setae ; paraglossae nearly 3.0x longer than wide, with distal row of long, relatively robust, simple setae ; palp segment 1 subequal to segments 2 and 3 combined ; palp segment 2 basally narrow, apically bulbous ; palp segment 3 conical.

\section{- THORAX}

Femora (Fig. 22) broad, dorsally and ventrally with abundant long, relatively robust, simple setae ; tibiae dorsally with short, fine, simple setae, and ventrally with long, relatively robust, simple setae ; tarsi dorsally with short, fine, simple setae, and ventrally with relatively long, robust, simple setae ; tarsal claws (Fig. 23 ) with two rows of minute denticles, more or less elliptically arranged.

\section{- ABDOMEN}

Terga (Fig. 24) without scales or scale bases, and with posterior marginal spines.

Gills (Fig. 25) on abdominal segments 1-7, ovate, poorly serrate at margins (Fig. 26).

Paraprocts (Fig. 27) with marginal spines.

Terminal filament subequal to cerci. 


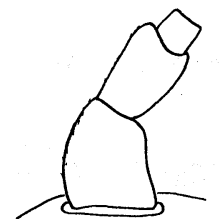

14

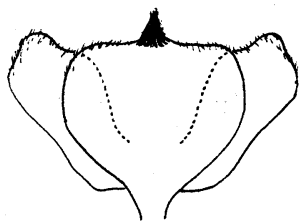

16

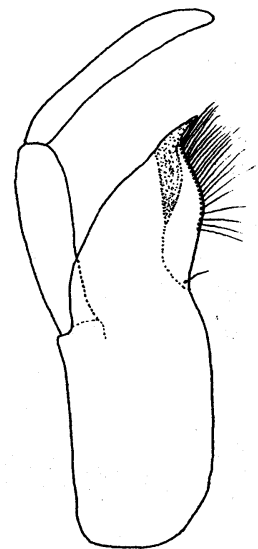

19

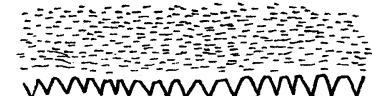

24

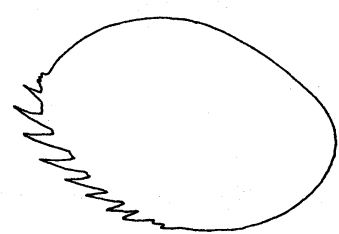

27

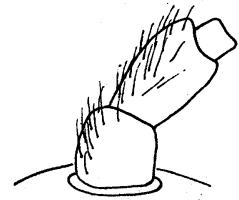

28

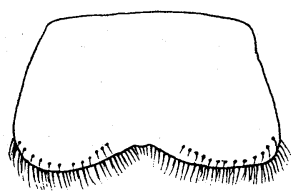

15

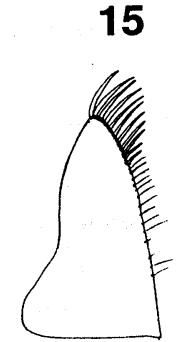

21

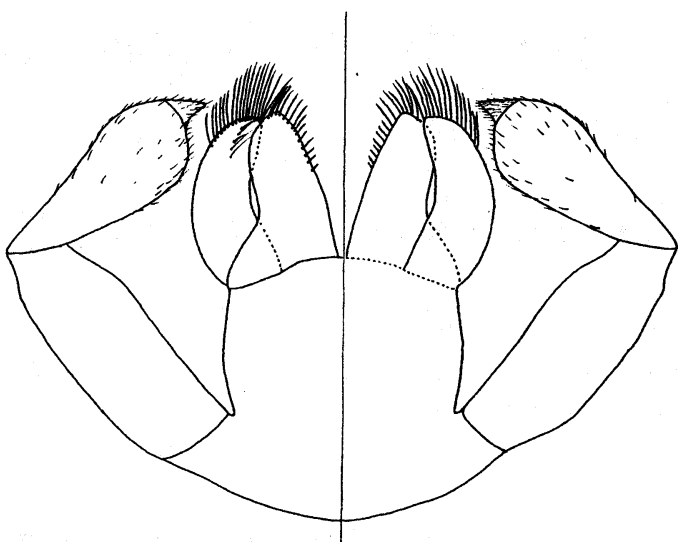

20

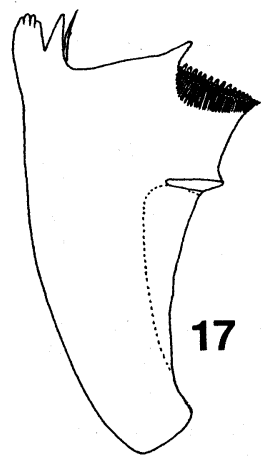

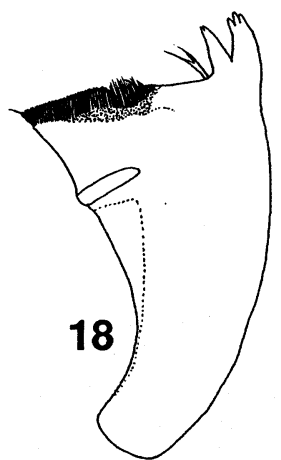

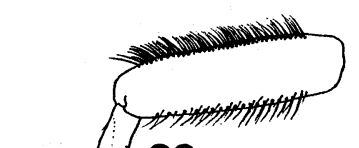

22
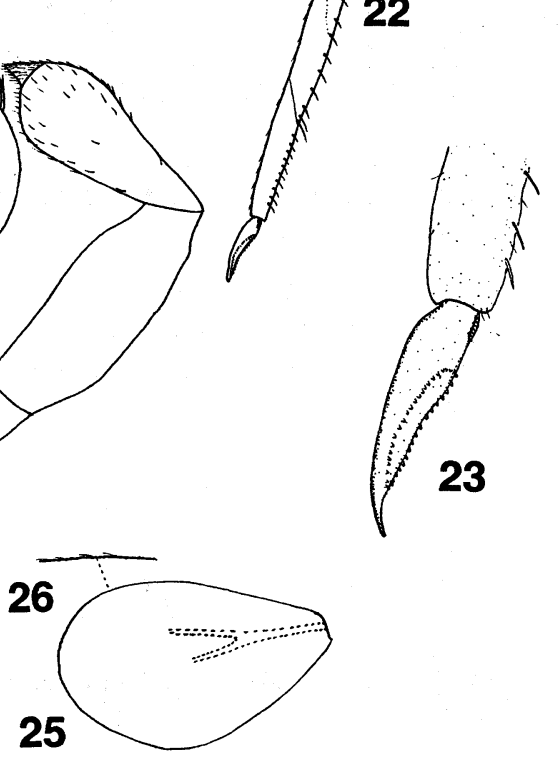

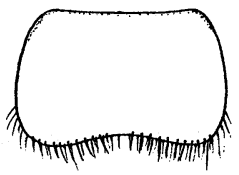

29

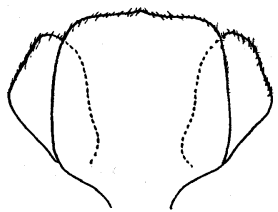

30

Figs. 14 to 30 . Larval structures of Rivudiva spp. 14 to 27 . Rivudiva minantenna. 14 : antennal scapes and pedicels. $15:$ labrum (dorsal). $16:$ hypopharynx. $17:$ left mandible. $18:$ right mandible. $19:$ right maxilla. $20:$ labium (left-ventral ; right-dorsal). $21:$ left glossa (enlarged). 22 : right foreleg. 23 : tarsal claw. 24 : tergum 4 (detail). 25 : gill 4.26 : gill 4 (detail of margin). 27 : paraproct. 28 to 30 . Rivudiva trichobasis. 28 : antennal scapes and pedicels. 29 : labrum (dorsal). 30 : hypopharynx.

Figs. 14 à 30. Structures larvaires de Rivudiva spp. 14 à 27 . Rivudiva minantenna. $14:$ scape et pédicelle. $15:$ labre (vue dorsale). $16:$ hypopharynx. 17 : mandibule gauche. $18:$ mandibule droite. $19:$ maxille droite. $20:$ labium (à gauche-vue ventrale ; à droite-vue dorsale); $21:$ glosse gauche (agrandie). 22 : patte antérieure droite. $23:$ griffe tarsale. $24:$ détail de la surface du $4^{\mathrm{e}}$ tergite. $25: 4 \mathrm{e}$ branchie. $26:$ détail du bord de la $4^{\mathrm{e}}$ branchie. 27 : paraprocte. 28 à 30 . Rivudiva trichobasis. 28 : scape et pédicelle antennaires. 29 : labre (vue dorsale). $30:$ hypopharynx. 
Adult

Unknown.

\subsection{Types species}

Rivudiva minantenna Lugo-Ortiz \& McCafferty, $\mathrm{n}$. $\mathrm{sp}$.

\subsection{Included species}

Rivudiva minantenna Lugo-Ortiz \& McCafferty, $\mathrm{n}$. sp. (larva) ; R. trichobasis Lugo-Ortiz \& McCafferty, n. sp. (larva).

\subsection{Distribution}

Brazil (Rio Grande do Sul, Santa Catarina), Paraguay.

\subsection{Etymology}

The generic name is an arbitrary combination of letters incorporating the Latin words rivus (river) and $d i$ $v a$ (goddess). The gender is feminine.

\subsection{Discussion}

Larvae of Rivudiva are distinguished by the broad lingua and relatively narrow superlinguae (Figs. 16, 30); general morphology of the labium (Fig. 20), particularly the broad glossae with a distomedial row of long, robust, falcate, simple setae (Fig. 21) ; and tarsal claws with minute denticles arranged in an ellipse (Fig. 23).

Larvae of Rivudiva are somewhat similar to those of the Panamerican genus Paracloeodes. However, larvae of Paracloeodes have a hypopharynx with relatively enlarged superlinguae (Lugo-Ortiz \& McCafferty 1996d : Fig. 2) ; the glossae do not have a broad base or distomedial row of long, robust, falcate, simple setae (Lugo-Ortiz \& McCafferty 1996d : Figs. 6, 18); and the tarsal claws have a single row of denticles (Lugo-Ortiz \& McCafferty 1996d : Figs. 10, 20).

\subsection{Rivudiva minantenna Lugo-Ortiz \& McCaffer- ty, n. sp.}

\subsubsection{Description}

\section{Larva}

Body length : 5.9-6.4 mm ; caudal filaments length : 1.9-2.0 mm.

\section{- HEAD}

Coloration pale yellow-brown, with no distinct color pattern.

Antennal scapes and pedicels (Fig. 14) bare ; scapes subequal in length to pedicels.
Labrum (Fig. 15) somewhat expanded anterolaterally, with relatively broad, deep anteromedian emargination and dorsally with anterior submarginal row of 10 12 long, fine, simple setae on either side of midline.

Hypopharynx (Fig. 16) with lingua dense tuft of long, relatively robust, simple setae anteromedially, superlinguae with relatively broad distal hump.

Left mandible as in Figure 17.

Right mandible as in Figure 18.

Maxillae (Fig. 19) with segment 1 subequal to segment 2.

Labium (Fig. 20) with palp segments 2 and 3 with short, fine, single setae scattered over surface.

- THORAX

Coloration pale yellow-brown, with no distinct color pattern.

Hindwingpads present.

Legs (Fig. 22) pale yellow-brown ; tarsal claws as in Figure 23.

\section{- ABDOMEN}

Coloration pale yellow-brown, with no distinct color pattern.

Terga (Fig. 24) with posterior triangular marginal spines somewhat irregular, but generally as long as wide.

Gills (Fig. 25) poorly tracheated ; middle gills as long as corresponding segments.

Paraprocts (Fig. 27) with 10-12 marginal spines, basal two and distal two or three smaller than rest.

Caudal filaments pale yellow-brown.

Adult

Unknown.

\subsubsection{Material examined}

Holotype : Larva, Brazil, Rio Grande do Sul State, Rio Santa Maria, $31^{\circ} 10^{\prime} \mathrm{S} / 54^{\circ} 23^{\prime} \mathrm{W}, 280 \mathrm{~m}$, XI-1964, F. Plaumann. Paratypes : Four larvae, same data as holotype (one larva deposited in the entomological collection of the Instituto-Fundación Miguel Lillo, Tucumán, Argentina) ; larva, Brazil, Rio Grande do Sul Sate, Pedro Osorio, $31^{\circ} 48^{\prime} \mathrm{S} /$ $52^{\circ} 45^{\prime} \mathrm{W}, 60 \mathrm{~m}, \mathrm{XI}-1964$, F. Plaumann [mouthparts, forelegs, tergum 3, and paraproct mounted on slide (medium : Euparal)] ; larva, Brazil, Santa Catarina State, Rio Iquererim, $26^{\circ} 02^{\prime}$ 'S / 48 $52^{\prime} \mathrm{W}, 10 \mathrm{~m}$, XI-1965, F. Plaumann [mouthparts, antenna, and tergum 4 mounted on slide (medium : Euparal)]. Additional material : Ten larvae, same data as holotype ; two larvae, Brazil, Rio Grande do Sul State, Pedro Osorio, 31 ${ }^{\circ} 48^{\prime} \mathrm{S} / 52^{\circ} 45^{\prime} \mathrm{W}, 60 \mathrm{~m}$, XI-1964, F. Plaumann. 


\subsubsection{Etymology}

The specific epithet is considered a noun in apposition, from the Latin antenna and combined with the modifier minus (bare). It is in reference to the absence of setae on the antennal scapes and pedicels of the larvae.

\subsubsection{Discussion}

Rivudiva minantenna differs from $R$. trichobasis in that the antennal scapes and pedicels are bare (Fig. 14) ; the labrum is somewhat expanded anterolaterally and has a relatively deep anteromedian emargination (Fig. 15) ; the lingua has a dense tuft of long, relatively robust, simple setae and the superlinguae have a distal hump (Fig. 16) ; hindwingpads are present ; and the abdomen lacks any color pattern.

\subsection{Rivudiva trichobasis Lugo-Ortiz \& McCafferty, n. sp.}

\subsubsection{Description}

Larva

Body length : 5.5-5.7 mm ; caudal filaments length : 1.5-1.7 mm.

- HEAD

Coloration yellow-brown, with no distinct color pattern.

Antennal scapes and pedicels (Fig. 28) with long, robust, simple setae ; scapes nearly $1.5 \mathrm{x}$ longer than pedicels.

Labrum (Fig. 29) not expanded anterolaterally, with shallow anteromedian emargination and dorsally with anterior marginal row of 10-12 long, fine, simple setae.

Hypopharynx (Fig. 30) with lingua anteromedially bare, superlinguae without distal hump.

Left mandible similar to Figure 17.

Right mandible similar to Figure 18.

Maxillae (similar to Fig. 19) with segment 2 slightly longer than segment 1.

Labium (similar to Figs. 20, 21) with palp segments 2 and 3 with short, fine, single setae scattered over surface.

\section{- THORAX}

Coloration pale yellow-brown, with no distinct color pattern ; metanotum with lateral medium brown spots.

Hindwingpads absent.

Legs (similar to Fig. 22) pale yellow-brown ; tarsal claws similar to Figure 23.

\section{- ABDOMEN}

Coloration pale yellow-brown; terga 3 and 6 with anteriorly broad and abruptly narrow medium brown markings resembling a spade. Terga (similar to Fig. 24) with posterior triangular marginal spines somewhat irregular, but generally as long as wide. Gills (similar to Fig. 25) poorly tracheated ; middle gills as long as one and one-quarter corresponding segments. Paraprocts (similar to Fig. 27) with 10-12 marginal spines, basal two and distal two or three spines smaller than the rest. Caudal filaments pale yellow-brown.

Adult

Unknown.

\subsubsection{Material examined}

Holotype : Larva, Brazil, Rio Grande do Sul State, Arroio dos Vargas, $30^{\circ} 50^{\prime} \mathrm{S} / 53^{\circ} 10^{\prime} \mathrm{W}, 120 \mathrm{~m}$, XI-1964, F. Plaumann. Paratypes : Five larvae, same data as holotype (one larva deposited in the entomological collection of the Instituto-Fundación Miguel Lillo, Tucumán, Argentina). Additional material : Twenty-five larvae, same data as holotype ; larva, Paragua, Departamento Paraguarí, Parque Nacional Ybycuí, Arroyo Mina, pool, IV-20-1984, R.T. Bonace.

\subsubsection{Etymology}

The specific epithet is a noun in apposition, combining the Greek trichos (hair) and basis (base). It is an allusion to the setose antennal scapes and pedicels of the larvae.

\subsubsection{Discussion}

Rivudiva trichobasis differs from $R$. minantenna in that the antennal scapes and pedicels have long, robust, simple setae (Fig. 28) ; the labrum is not expanded anterolaterally and has a relatively shallow anteromedian emargination (Fig. 29 ) ; the lingua does not have an anteromedial tuft of setae and the superlinguae do not have a distal hump (Fig. 30); hindwingpads are absent ; and abdominal segments 3 and 6 have spade shaped medium brown markings.

\section{Spiritiops Lugo-Ortiz \& McCafferty, n. gen.}

\subsection{Description \\ Larva \\ - HEAD}

Frontal keel absent.

Antennae with pedicels subequal in length to scapes.

Labrum (Fig. 31) broadly rounded anteriorly, with deep anteromedial notch.

Hypopharynx (Fig. 32) with broad lingua and superlinguae. 


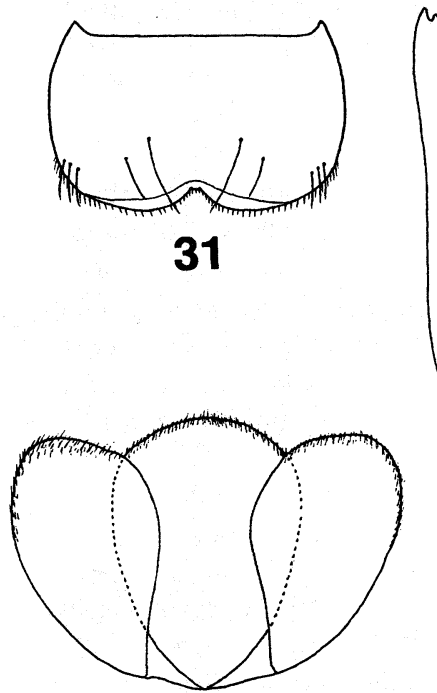

32

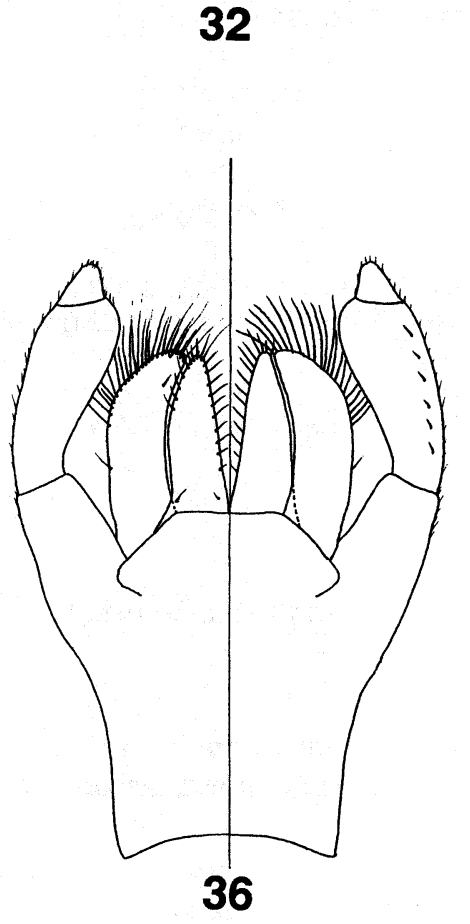

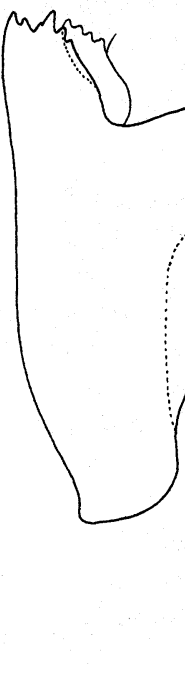
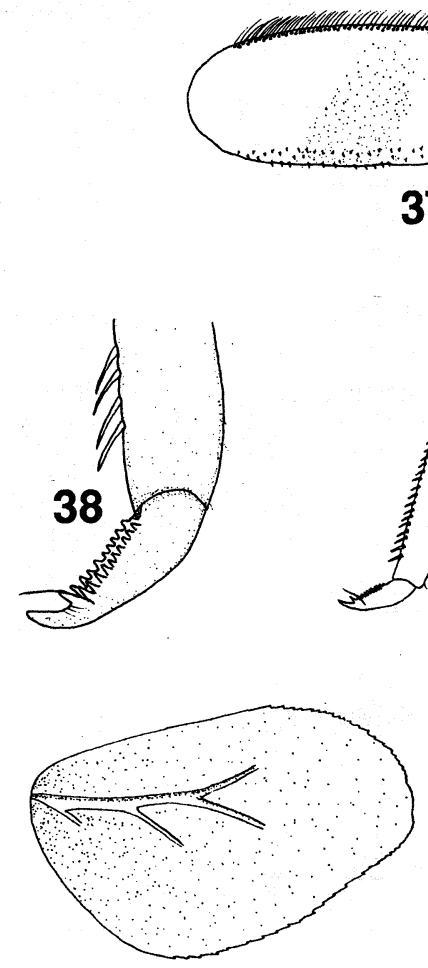

40
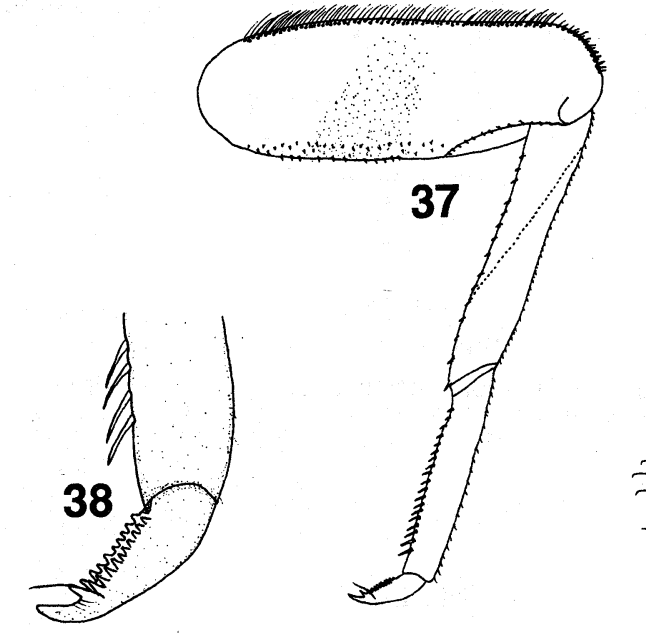

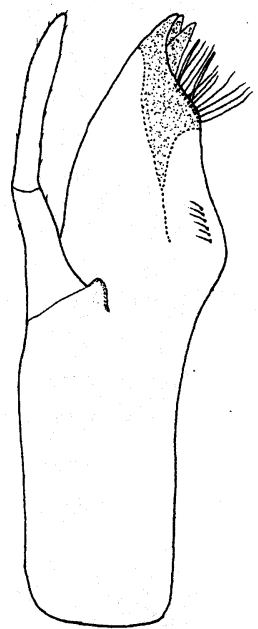

35

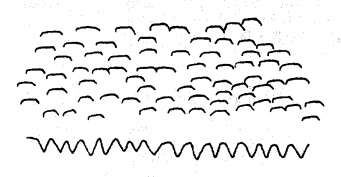

39

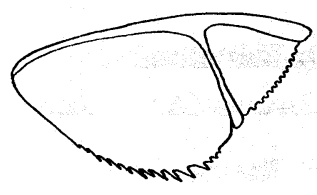

41

Figs. 31 to 41. Larval structures of Spiritiops silvudus. 31 : labrum (dorsal). 32 : hypopharynx. $33:$ left mandible. 34 : right mandible. $35:$ right maxilla. 36 : labium (left-ventral ; right-dorsal). $37:$ left foreleg. $38:$ tarsal claw. $39:$ tergum 4 (detail). $40:$ gill $4.41:$ paraproct.

Figs. 31 à 41 . Structures larvaires de Spiritiops silvudus. $31:$ labre (vue dorsale). 32 : hypopharynx. $33:$ mandibule gauche. $34:$ mandibule droite. $35:$ maxille droite. $36:$ labium (à gauche-vue ventrale; à droite-vue dorsale). $37:$ patte antérieure gauche. $38:$ griffe tarsale. $39:$ détail de la surface du 4 e tergite. $40: 4^{\mathrm{e}}$ branchie. $41:$ paraprocte. 
Mandibles (Figs. 33, 34) with incisors basally fused, denticles distinct ; prostheca of left mandible robust, apically denticulate, with long, fine, simple seta arising distomedially ; prostheca of right mandible robust, apically denticulate, with long, robust, pilose seta arising from medial margin in middle region ; right mandible with tuft of long, fine, simple setae present between prostheca and mola.

Maxillae (Fig. 35) with two-segmented palps, not reaching galealaciniae ; crown of galaelaciniae with four denticles.

Labium (Fig. 36) with glossae as long as paraglossae ; paraglossae nearly $3.5 \mathrm{x}$ longer than wide ; palp segment 1 subequal to segments 2 and 3 combined; palp segment 2 basally narrow, apically broad ; palp segment 3 conical.

\section{- THORAX}

Femora (Fig. 37) broad, without villopore ; tarsal claws (Fig. 38) with two rows of denticles and long, fine, subapical seta laterally.

\section{- ABDOMEN}

Terga (Fig. 39) with scale bases and posterior marginal spination.

Gills (Fig. 40) on abdominal segments 1-7, serrate at margins.

Paraprocts (Fig. 41) with marginal spines.

Terminal filament nearly $0.80 x$ length of cerci.

Adult

Unknown.

\subsection{Type species}

Spiritiops silvudus Lugo-Ortiz \& McCafferty, n. sp.

\subsection{Included species}

Spiritiops silvudus Lugo-Ortiz \& McCafferty, n. sp. (larva).

\subsection{Distribution}

Brazil (Amazonas, Pará), French Guyana.

\subsection{Etymology}

The generic name is an arbitrary combination letters incorporating the Latin word spiritus (spirit) and the Greek word iops (fish). The gender is masculine.

\subsection{Discussion}

Larvae of Spiritiops are distinguished by the right mandible having the prostheca with a long, robust, pilose seta arising from its medial margin and a tuft of long, fine, simple setae present between the prostheca and mola (Fig. 34) and tarsal claws with two rows of denticles and a lateral long, fine, simple seta (Fig. 38). The presence of the tarsal seta places Spiritiops in the New World Baetodes complex of genera (Baetodes, Mayobaetis, Moribaetis, and Prebaetodes) because that is one of the defining apomorphies of the complex (Lugo-Ortiz \& McCafferty 1996a). In addition, the general morphology of the labium (Fig. 36), two rows of denticles in the tarsal claws (Fig. 38), and general morphology of the abdominal gills (Fig. 40) are highly reminiscent of a complex of the Afrotropical genera, including Acanthiops Waltz \& McCafferty, Afroptilum Gillies sensu stricto (with respect to its type species and closely related species only) Centroptiloides Lestage, Dicentroptilum Wuillot \& Gillies, and Nesoptiloides Demoulin, and possibly others (Lugo-Ortiz \& McCafferty, unpublished). It is possible that Spiritiops is related to those genera, and that Spiritiops indicates a link between the New World and Afrotropical complex of genera. If the adults of Spiritiops prove to have single marginal intercalaries in the forewings, as do the Afrotropical complex mentioned, then we would be inclined to view the presence of the single tarsal claw seta in Spiritiops and the Baetodes complex as convergent. On the other hand, if adults prove to have double marginal intercalaries, then a case could be made for a plesiotypic position within the Baetodes complex. An assessment of the polarity of character states shared with the Afrotropical complex will be necessary before a further analysis of the relationships of Spiritiops can be undertaken.

\subsection{Spiritiops silvudus Lugo-Ortiz \& McCafferty, n. sp.}

\subsubsection{Description}

Larva

Body length : 4.0-5.1 mm ; caudal filaments length : 2.3-2.9 mm.

\section{- HEAD}

Coloration medium brown to medium yellowbrown, frons and vertex generally with faint vermiform markings.

Antennae nearly 3.0x length of head capsule ; scapes and pedicels with minute, fine, simple setae scattered over surface.

Labrum (Fig. 31) dorsally with two submedial long, fine, simple setae on either side.

Hypopharynx as in Figure 32.

Left mandible (Fig. 33) $2+4$ denticles.

Right mandible (Fig. 34) with $3+3$ denticles. 
Maxillae (Fig. 35) with palps with short, fine, simple setae scattered over surface ; palp segment 1 subequal to segment 2 ; five to six long, fine, simple setae present near medial hump.

Labium (Fig. 36) with glossae with two or three short, fine, simple setae scattered over ventral surface, 8-10 long, relatively robust, simple setae medially, and 10-12 long, relatively robust, simple setae distally ; paraglossae with apical row of long, relatively robust setae distally ; palp segment 1 bare ; palp segments 2 and 3 with short, fine, simple setae scattered over surface ; palp segment 2 dorsally with five to six long, fine, simple setae.

\section{- THORAX}

Coloration medium yellow-brown ; pronotum with complex faint markings.

Hindwingpads present.

Legs (Fig. 37) light yellow-brown ; femora with anterior medium brown marking, dorsally with row of long, relatively robust, simple setae, ventrally with short, stout, simple setae scattered over surface ; tibiae dorsally with numerous short, fine simple setae and ventrally with short, relatively robust, simple setae scattered over surface ; tarsi dorsally with numerous short, fine, simple setae and ventrally with robust, simple setae increasing in length distally ; tarsal claws (Fig. 38) with 8-10 denticles in both rows, distal denticle largest.

\section{- ABDOMEN}

Coloration light and medium yellow-brown ; terga 1 and 2 medium yellow-brown, with no markings ; terga 3, 4, 6 and 7 medium brown, with faint small spots anteriorly in midregion; terga 5, 8 and 10 light yellowbrown, laterally medium yellow-brown; tergum 9 anteriorly light yellow-brown, posteriorly medium yellow brown.

Terga (Fig. 39) with posterior triangular marginal spines somewhat irregular, almost as long as basally wide.

Gills (Fig. 40) somewhat tracheated ; middle gills twice as long as corresponding segments.

Paraprocts (Fig. 41) marginally with 12-14 spines, increasing in length distally.

Caudal filaments pale yellow-brown, generally with faint brown band medially.

\section{Adult}

Unknown.

\subsubsection{Material examined}

Holotype : Larva, Brazil, Amazonas State, Cachoeira do Traira Cr, nr Rio Cuieiras, waterfall, N of Manaus, 16-XII-
1960, E.J. Fittkau. Paratypes : Six larvae, same data as holotype (mouthparts and forelegs of larva mounted on slide [medium : Euparal]) (one larva deposited in the entomological collection of the Instituto-Fundación Miguel Lillo, Tucumán, Argentina) ; three larvae, Brazil, Amazonas State, Traira rapids, N of Manaus, 19-XII-1960, E.J. Fittkau ; larva, Brazil, Amazonas State, Pataná Cr, $300 \mathrm{~m}$ above jct with Rio Cuieiras, N of Manaus, 18-IV-1961, E.J. Fittkau ; larva, Brazil, Amazonas State, Gigante Cr, rapids, Reserva Duke, $\mathbf{N}$ of Manaus, 3-VII-1961, E.J. Fittkau ; larva, Brazil, Amazonas State, Rio Branquinho, waterfall, $\mathrm{nr}$ Rio Cuieiras, $\mathrm{N}$ of Manaus, 22-VII-1961, E.J. Fittkau (mouthparts and forelegs mounted on slide [medium : Euparal]) ; five larvae, Brazil, Amazonas State, Cachoeira Cr, $\mathrm{nr}$ Rio Cuieiras, $\mathrm{N}$ of Manaus, 27-XI-1962, E.J. Fittkau. Additional material : Brazil : Amazonas State : Nine larvae, Cachoeira do Traira Cr, nr Rio Cuieiras, waterfall, N of Manaus, 16-XII-1960, E.J. Fittkau ; five larvae, Cachoeira Cr, nr Rio Cuieiras, $\mathrm{N}$ of Manaus, 17XII-1960, E.J. Fittkau ; three larvae, Traira rapids, $\mathrm{N}$ of Manaus, 19-XII-1960, E.J. Fittkau ; two larvae, Cachoeira Cr, nr Acapamento, $\mathrm{N}$ of Manaus, 18-IV-1961, E.J. Fittkau ; 11 larvae, Pataná Cr, $300 \mathrm{~m}$ above jct with Rio Cuieiras, $\mathrm{N}$ of Manaus, 18-IV-1961, E.J. Fittkau ; 36 larvae, Rio Branquinho, waterfall, nr Rio Cuieiras, N of Manaus, 22-VII-1961, E.J. Fittkau ; two larvae, Pedras Cr, nr Rio Aripuana, 18-I-1962, E.J. Fittkau ; five larvae, Cachoeira $\mathrm{Cr}$, $\mathrm{nr}$ Rio Cuieiras, $\mathrm{N}$ of Manaus, 27-XI-1962, E.J. Fittkau. Pará State : Six larvae, Rio Cururú, nr Creputia rapids, 26-I-1961, E.J. Fittkau ; larva, Rio Paru, nr Tiriyos Mission, nr Brazil-Suriname border, 31-III-1963, E.J. Fittkau. French Guyana : Four larvae, Sinnamary R, Saut Takari-Tanté, 24-V-1992, V. Horeau, larvae ; larva, Sinnamary R, Saut Deux Roros, 1-XI-1992, V. Horeau.

\subsubsection{Etymology}

The specific epithet combines the Latin roots silva (forest) and udus (wet). It is an allusion to the Amazonian rain forest, from where the species is known.

\subsubsection{Discussion}

The setation of the labrum (Fig. 31), mandibular denticulation (Figs. 33, 34), presence of hindwingpads, and leg (Fig. 37) and abdominal coloration may prove to be of diagnostic importance at the species level.

\section{Varipes Lugo-Ortiz \& McCafferty, n. gen.}

\subsection{Description}

Larva

- HEAD

Frontal keel absent.

Antennae with pedicels subequal in length to scapes (Fig. 42). 


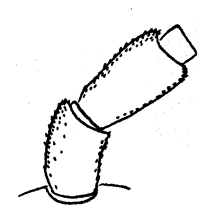

42

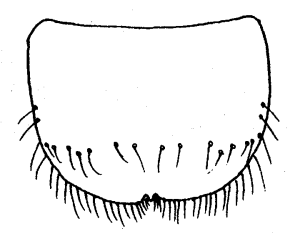

43

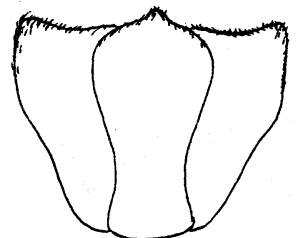

44
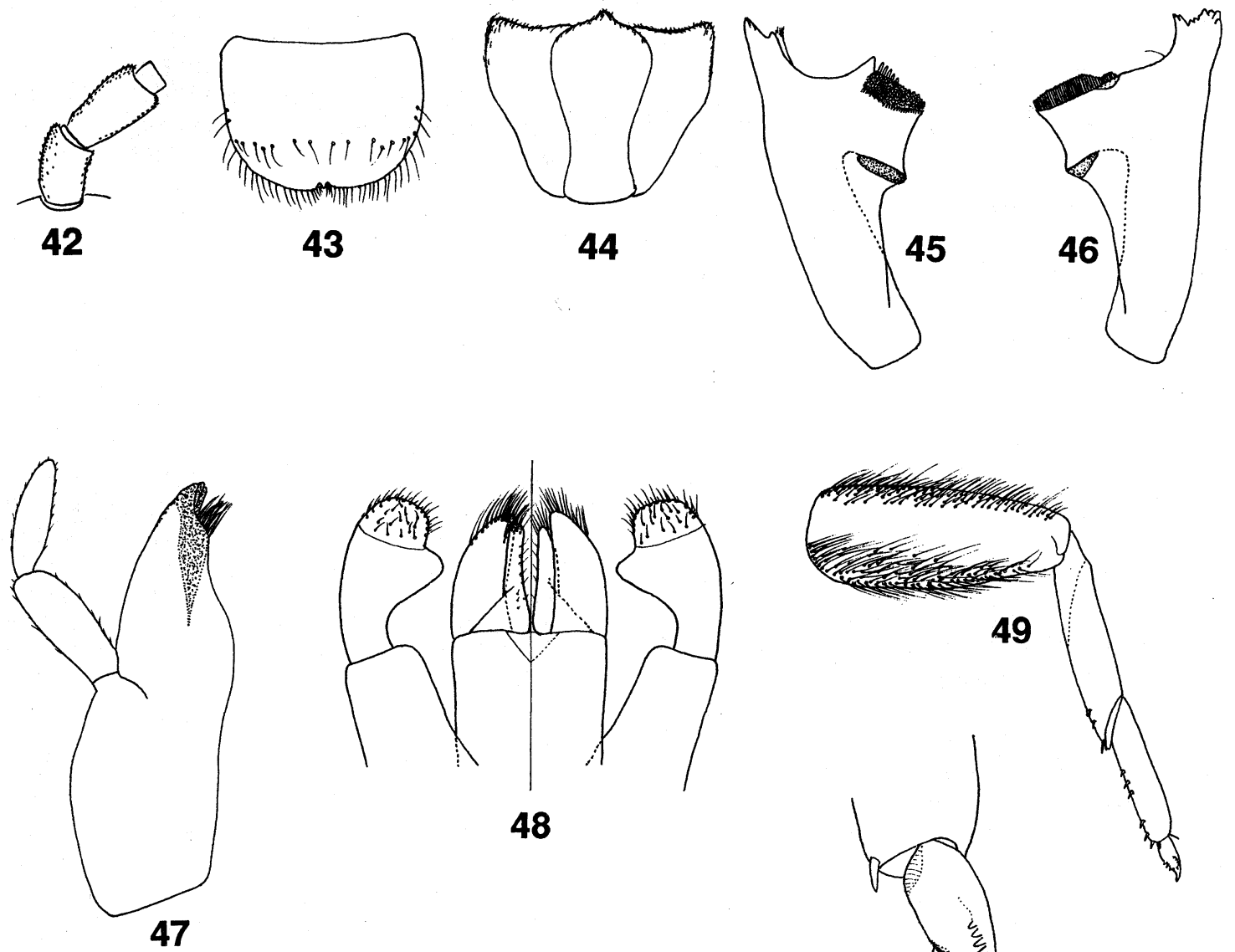

48
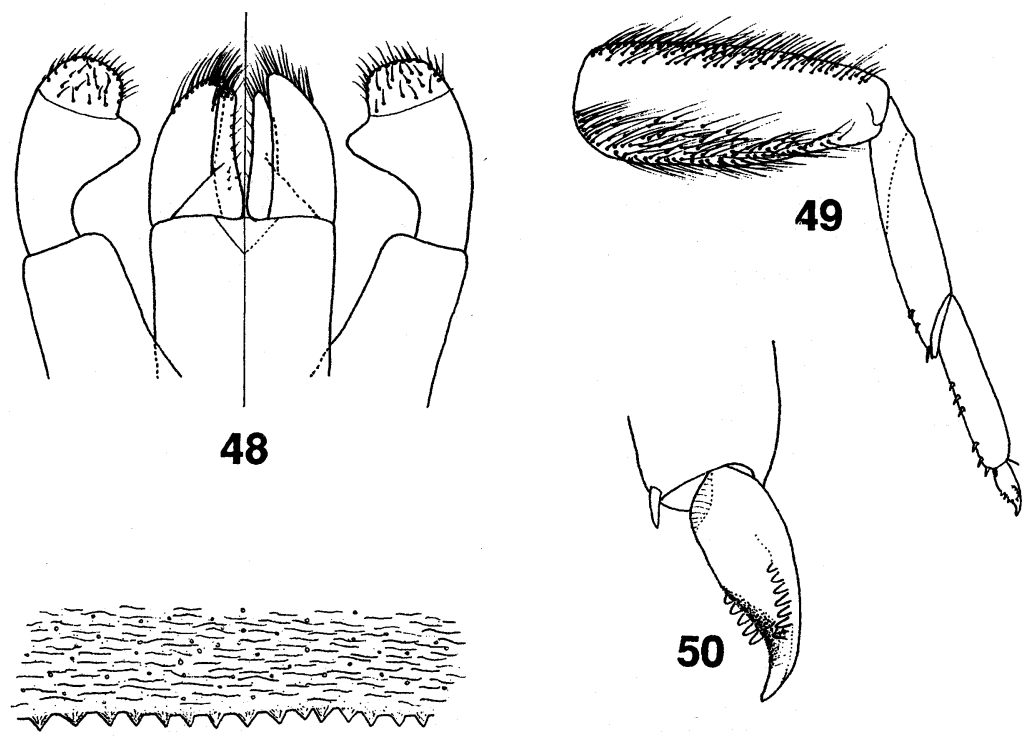

51

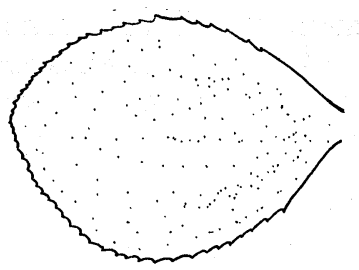

52

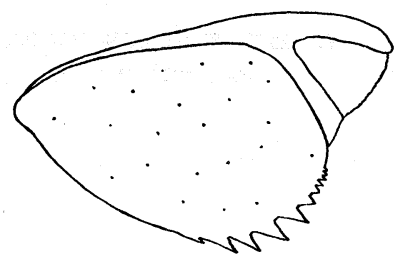

53

Figs. 42 to 53. Larval structures of Varipes lasiobrachius. 42 : antennal scapes and pedicels. 43 : labrum (dorsal). 44 : hypopharynx. 45 : left mandible. 46 : right mandible. 47 : right maxilla. 48 : labium (left-ventral ; right-dorsal). 49 : left foreleg. $50:$ tarsal claw. 51 : tergum 4 (detail). 52 : gill 4.53 : paraproct.

Figs. 42 à 53. Structures larvaires de Varipes lasiobrachius. $42:$ scape et pédicelle. 43 : labre (vue dorsale). $44:$ hypopharynx. $45:$ mandibule gauche. 46 : mandibule droite. $47:$ maxille droite. $48:$ labium (à gauche-vue ventrale ; à droite-vue dorsale). $49:$ patte antérieure gauche. 50 : griffe tarsale. $51:$ détail de la surface du 4 e tergite. $52: 4^{\mathrm{e}}$ branchie. $53:$ paraprocte. 
Labrum (Fig. 43) broadly rounded anteriorly, with small medial notch.

Hypopharynx (Fig. 44) with relatively broad lingua and superlinguae.

Mandibles (Figs. 45, 46) with incisors basally fused, denticles distinct ; prostheca of left mandible robust, apically acute ; prostheca of right mandible reduced to long, fine, simple seta.

Maxillae (Fig. 47) with two-segmented palps, reaching galealaciniae ; crown of galealaciniae with four denticles.

Labium (Fig. 48) with glossae subequal in length to paraglossae ; paraglossae nearly $2.25 x$ longer than wide ; palp segment 1 as long as segments 2 and 3 combined; palp segment 2 with moderately developed and somewhat narrowly pointed distomedial process ; palp segment 3 broadly rounded.

\section{- THORAX}

Femora (Fig. 49) broad ; tarsal claws (Fig. 50) with two marginal rows of denticles, almost forming a $U$.

\section{- ABDOMEN}

Terga (Fig. 51) without scales or scales bases.

Gills (Fig. 52) on abdominal segments 1-7, marginally well serrate.

Paraprocts (Fig. 53) with marginal spines.

Terminal filament subequal in length to cerci.

Adult

Unknown.

\subsection{Type species}

Varipes lasiobrachius Lugo-Ortiz \& McCafferty, n. sp.

\subsection{Included species}

Varipes lasiobrachius Lugo-Ortiz \& McCafferty, n. sp. (larva).

\subsection{Distribution}

Colombia, Ecuador, Peru.

\subsection{Etymology}

The generic name is an arbitrary combination of the Latin roots varius (different) and pes (foot), an allusion to the unique tarsal claws. The gender is masculine.

\subsection{Discussion}

Varipes is unique in Baetidae because the right prostheca is reduced to a long, fine, simple seta (Fig. 46), and the tarsal claws have a peculiar arrangement of denticles consisting of two marginal rows tending to form a $U$ (Fig. 50). Phylogenetic affinities of the genus are impossible to determine at this time. The general morphology of the labium (Fig. 48), however, is very similar to that of the South American species Camelobaetidius musseri (Traver \& Edmunds) (Traver \& Edmunds 1968 : Fig. 81) and C. anubis (Traver \& Edmunds) (Travers \& Edmunds 1968 : Fig. 82), suggesting that Varipes is perhaps related to Camelobaetidius.

Traver \& Edmunds (1968) provided figures of the tarsal claws of one larva collected in Peru (Traver \& Edmunds 1968 : Figs. 88, 89) that are similar to those of Varipes (Fig. 50). They indicated that the larva probably represented a new genus, but did not describe it because their specimen was in poor condition. We have not seen a similar arrangement of denticles in the tarsal claws of any other South American Baetidae, and therefore conclude that the Traver Edmunds (1968) specimen belongs to Varipes.

\subsection{Varipes lasiobrachius Lugo-Ortiz \& McCaffer- ty, n. sp.}

\subsubsection{Description}

\section{Larva}

Body length : 4.3-5.8 mm ; caudal filaments length : 1.9-2.4 mm.

- HEAD

Coloration dark yellow-brown to medium brown, with no distinct color pattern.

Antennal scapes and pedicels with minute, stout, simple setae scattered over surface (Fig. 42).

Labrum (Fig. 43) dorsally with long, fine, simple setae scattered on anterior one third and numerous long, fine, simple setae on anterior margin.

Hypopharynx as in Figure 44.

Left mandible (Fig. 45) with $3+1$ denticles.

Right mandible (Fig. 46) with $6+2$ denticles.

Maxillae (Fig. 47) with palps with short, fine, simple setae scattered over surface ; segment 2 nearly $0.75 x$ length of segment 1 .

Labium (Fig. 48) with glossae with short, fine, simple setae scattered over ventral surface, four to six long, fine, simple setae medially, and numerous long, fine, simple setae distally ; paraglossae with apical row of long, fine, simple setae ; palp segments 1 and 2 bare ; palp segment 3 with numerous long, fine, simple setae scattered over surface.

\section{- THORAX}

Coloration dark yellow-brown to dark brown ; pronotum generally dark yellow-brown to dark brown, 
posterior half of mesonotum (including wingpads) and entire metanotum generally pale yellow-brown.

Hindwingpads absent.

Legs (Fig. 49) yellow-brown ; femora dorsally and ventrally with abundant long, robust, simple setae ; tibiae dorsally bare, ventrally with three to five short, stout, simple setae apically ; tarsi dorsally bare, ventrally with six to eight short, stout, simple setae randomly distributed ; tarsal claws (Fig. 50) with six to seven denticles on lateral and medial margins.

\section{- ABDOMEN}

Coloration pale and dark yellow-brown; segments 1 , 4-6, 9, 10 generally pale yellow-brown, other segments dark yellow-brown.

Terga (Fig. 51) with posterior triangular marginal spines as long as basally wide.

Gills (Fig. 52) poorly tracheated ; gills 1 and 2 lightly suffused with purplish dots, other gills whitish to translucent ; gills 1, 2 and 7 somewhat elongate, other gills nearly $1.33 x$ longer than wide.

Paraprocts (Fig. 53) marginally with 8-10 spines, apical four to five spines smaller than others.

Caudal filaments pale yellow-brown.

Adult

Unknown.

\subsubsection{Material examined}

Holotype : Larva, Ecuador, Napo Province, $6.2 \mathrm{~km} \mathrm{~S}$ of Baeza (old town), $1865 \mathrm{~m}, 16^{\circ} \mathrm{C}, 21-\mathrm{VII}-1993$, Sites, Linit, Nichols. Paratypes : Larva, same data and deposition as holotype (mouthparts, forelegs, tergum 4 mounted on slide [medium : Euparal]) ; larva, Ecuador, Pichincha Province, Río Guajalito at Las Palmeras, $36.2 \mathrm{~km}$ NE on Old Quito Rd, $1949 \mathrm{~m}, 15^{\circ} \mathrm{C}$, 19-VII-1993, Sites, Linit, Nichols (deposited in the entomological collection of the University of Missouri, Columbia). Additional material : Larva, Colombia, Cundinamarca Province, Quebrada Colorado, km 94 between Villavicencio and Bogotá, 13-IV-1969. W.P. McCafferty ; five larvae, Colombia, Meta Province, Río Sardinata between Villavicencio and Acacias, 9-IV-1969, W.P. McCafferty.

\subsubsection{Etymology}

The specific epithet is taken as a compound adjective, hairy legged, combining the Greek roots lasios (hairy) and brachios (arm). It is an allusion to the setose legs of the larvae.

\subsubsection{Discussion}

The arrangement of mandibular denticles (Figs. 45, 46), setose femora (Fig. 49), absence of hindwingpads, and body coloration should prove to be of specific diagnostic value.
It is possible that $V$. lasiobrachius is confined to relatively high altitudes in South America and may be the only representative of the genus. We have examined extensive materials from the continent and have been unable to find other species assignable to Varipes.

\section{Zelusia Lugo-Ortiz \& McCafferty, n. gen.}

\subsection{Description}

Larva

- HEAD

Frontal keel present.

Antennae with scapes longer than pedicels.

Labrum (Fig. 54) broadly anteriorly, medially raised, with small anteromedial notch.

Hypopharynx (Fig. 55) with broad, ovoid lingua and narrow superlinguae.

Mandibles (Figs. 56, 57) with incisors basally fused, denticles distinct ; prostheca of left mandible robust, apically denticulate ; prostheca of right mandible bifid, with short, fine, simple setae.

Maxillae (Fig. 58) with two-segmented palps, extending beyond galealaciniae; crown of galealaciniae with four denticles.

Labium (Fig. 59) with glossae subequal to paraglossae ; paraglossae nearly $2.25 x$ longer than wide ; palp segment 1 as long as segments 2 and 3 combined; segment 2 nearly $1.8 x$ length of segment 3 ; segment 3 broadly rounded.

\section{- THORAX}

Femora (Fig. 60) broad, without villopore ; tarsal - claws (Fig. 61) with single row of denticles.

- ABDOMEN

Terga (Fig. 62) with scales and posterior marginal spination.

Gills (Fig. 63) on abdominal segments 2-7, serrate at margins.

Paraprocts (Fig. 64) with marginal spines.

Terminal filament subequal in length to cerci.

Adult

Unknown.

\subsection{Type species}

Zelusia principalis Lugo-Ortiz \& McCafferty, n. sp.

\subsection{Included species}

Zelusia principalis Lugo-Ortiz \& McCafferty, n. sp. (larva). 


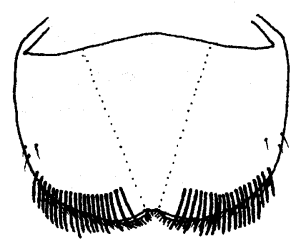

54

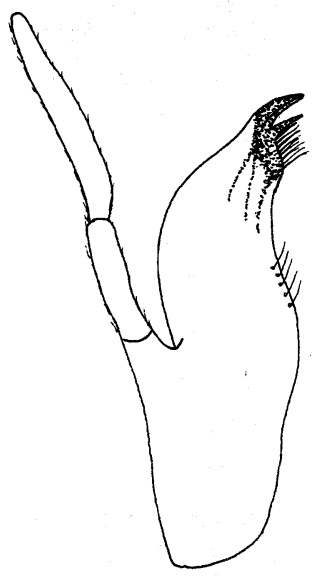

58

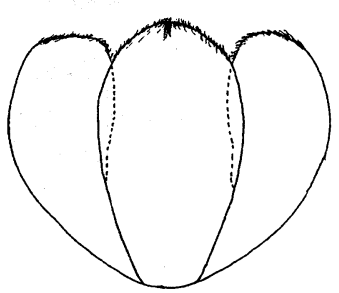

55
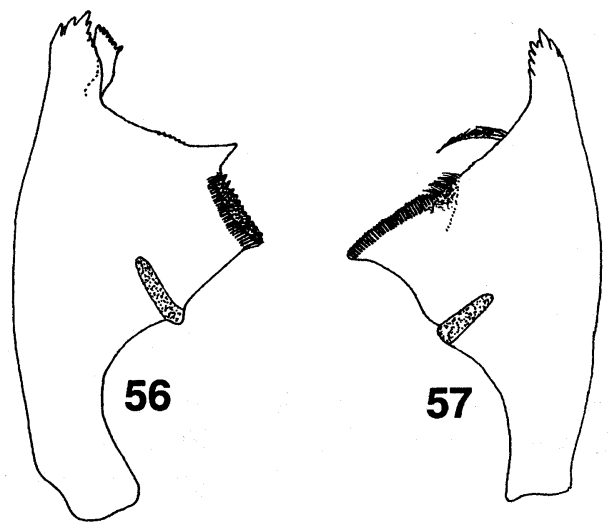

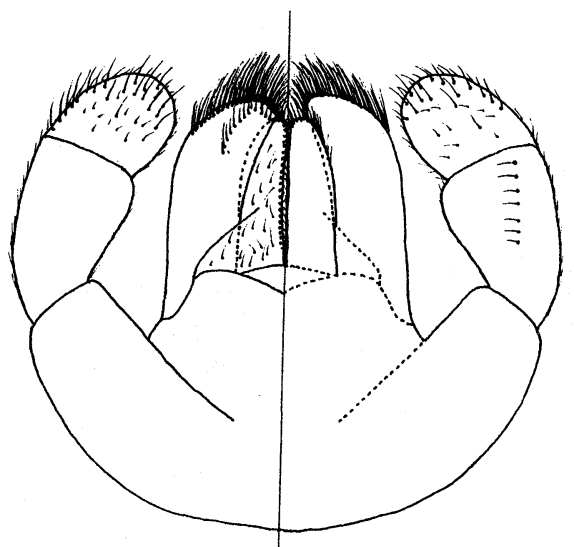

59
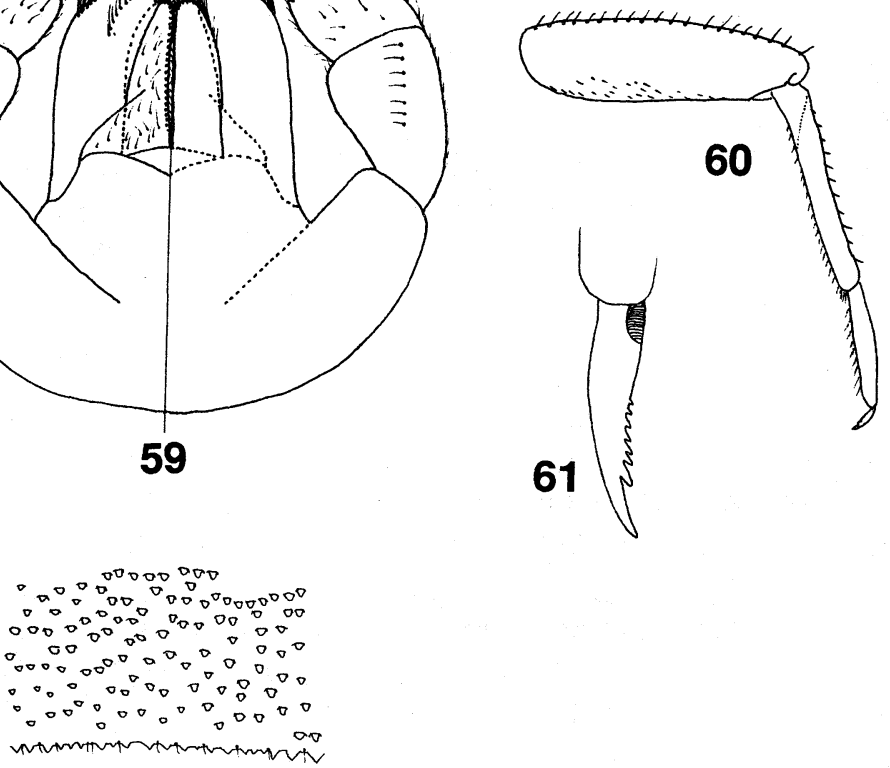

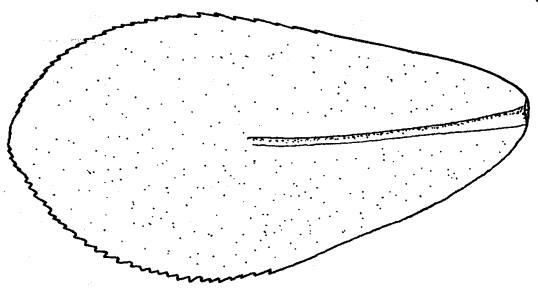

63

\section{2}

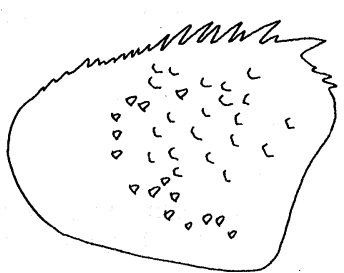

64

Figs 54 to 64. Larval structures of Zelusia principalis. 54 : labrum (dorsal). $55:$ hypopharynx. $56:$ left mandible. $57:$ right mandible. $58:$ right maxilla. 59 : labium (left-ventral ; right-dorsal). 60 : left foreleg. 61 : tarsal claw. 62 : tergum 4 (detail). $63:$ gill $4.64:$ paraproct.

Figs 54 à 64. Structures larvaires de Zelusia principalis. $54:$ labre (vue dorsale). $55:$ hypopharynx. $56:$ mandibule gauche. $57:$ mandibule droite. 58 : maxille droite. $59:$ labium (à gauche-vue ventrale; à droite-vue dorsale). $60:$ patte antérieure gauche. $61:$ griffe tarsale. $62:$ détail de la surface du $4^{\mathrm{e}}$ tergite. $63: 4^{\mathrm{e}}$ branchie. 64 : paraprocte. 


\subsection{Distribution}

Brazil (Amazonas, Pará), Colombia.

\subsection{Etymology}

The generic name is an arbitrary combination of letters incorporating the Latin word zelus (ardor, enthusiasm). The gender is feminine.

\subsection{Discussion}

Larvae of Zelusia are distinguished by the medially raised labrum (Fig. 54), bifid right prostheca (Fig. 57), and long and slender maxillary palps (Fig. 58). The genus is generally similar to the Arctogean genus Baetis Leach ; however, Zelusia lacks the villopore, and therefore cannot be considered related to Baetis or any of its cognate genera (Waltz et al. 1994).

\subsection{Zelusia principalis Lugo-Ortiz \& McCafferty, n. sp.}

\subsubsection{Description}

Larva

Body length : $3.8-4.2 \mathrm{~mm}$; caudal filaments length : 1.5-1.7 mm.

\section{- HEAD}

Coloration yellow-brown, with no distinct color pattern.

Antennal scapes and pedicels with minute, fine, simple setae scattered over surface.

Labrum (Fig. 54) dorsally with 18-20 long, robust, simple setae on either side of midline.

Hypopharynx as in Figure 55.

Left mandible (Fig. 56) with $3+5$ denticles ; base of triangular process at base of mola serrated.

Right mandible (Fig. 57) with $3+5$ denticles ; small tuft of short, fine, simple setae at base of mola.

Maxillae (Fig. 58) with palps with short, fine, simple setae scattered over surface ; segment 1 nearly $0.60 \mathrm{x}$ length of segment 2.

Labium (Fig. 59) with glossae with short, fine, simple setae medially and long, fine, simple setae laterally, and with short, fine, simple setae scattered over ventral surface ; paraglossae with two rows of long, fine, simple setae distally; palp segment 1 bare ; palp segment 2 with dorsal row of six to eight long, fine, simple setae and short, fine, simple setae scattered over surface ; palp segment 3 with short and long, fine, simple setae scattered over surface.

\section{- THORAX}

Coloration yellow-brown, with no distinct color pattern.
Hindwingpads absent.

Legs (Fig. 60) yellow-brown; femora dorsally with 16-18 long, fine, simple setae, ventrally with short, fine, simple setae scattered over surface ; tibiae with 810 long, fine, simple setae dorsally and numerous short, fine, simple setae ventrally ; tarsi dorsally bare, ventrally with 8-10 long, fine, simple setae ; tarsal claws (Fig. 61) with six to eight small, somewhat translucent denticles.

\section{- ABDOMEN}

Coloration yellow-brown, with no distinct color pattern.

Terga (Fig. 62) with somewhat irregular posterior triangular marginal spines ; short, fine, simple setae randomly arranged between spines.

Gills (Fig. 63) poorly tracheated, whitish to translucent ; middle gills as long as one and one-quarter corresponding segments.

Paraprocts (Fig. 64) marginally with numerous irregular spines.

Caudal filaments cream to pale yellow-brown.

Adult

Unknown.

\subsubsection{Material examined}

Holotype : Larva, Brazil, Amazonas State, mountain stream 2, nr Rio Marauia, $3 \mathrm{~d}$ trip above Santo Antônio Mission, NW of Taparuquara, 26-27-I-1963, E.J. Fittkau [mouthparts, forelegs, and tergum 4 mounted on slide (medium : Euparal)]. Paratypes : Larva, Brazil, Amazonas State, Passarinho Cr, Roca Antônio, Santo Antônio, $15 \mathrm{~km} \mathrm{~N}$ of Manaus, 12-XII-1961, E.J. Fittkau ; larva, Brazil, Amazonas State, waterfall, nr Santo Antônio Mission, Rio Marauia, NW of Taparuquara, 8-I-1963, E.J. Fittkau ; larva, Colombia, Cundinamarca Province, Caño $5 \mathrm{~km}$ from Albán, on Hwy 166, 3IV-1969, W.P. McCafferty [mouthparts, forelegs, tergum 4, and paraproct mounted on slide (medium : Euparal)]. Additional material : Brazil : Amazonas State : Larva, Jararaca Cr, 16-IX-1952, H. Sioli ; larva, Jaraca Cr, 18-IX-1952, H. Sioli ; two larvae, Cr nr Canal of Lago Grande, nr Santo Antônio do Içá, 7-X-1958, H. Sioli and W. Sattler ; three larvae, Barro Branco Cr, Reserva Duke, N of Manaus, 3-XII-1960, E.J. Fittkau ; three larvae, Rio Negro, jct with cold water stream, Manaus, 14-XII-1960, E.J. Fittkau ; three larvae, Pataná Cr; $300 \mathrm{~m}$ above jct with Rio Cuieiras, $\mathrm{N}$ of Manaus, 18-IV1961, E.J. Fittkau ; two larvae, Cachoeria do Traira, nr Rio Cuieiras, N of Manaus, 19-IV-1961, E.J. Fittkau ; two larvae, Barro Branco Cr, Reserva Duke, N of Manaus, 8-V-1961, E.J. Fittkau ; larva, Bica Cr, nr Ponta Negra, Rio Negro, N of Manaus, 23-VI-1961, E.J. Fittkau ; larva, Gigante Cr, nr Ponta Negra, Rio Negro, N of Manaus, 23-VI-1961, E.J. Fittkau ; two larvae, Acara Cr, Reserva Duke, N of Manaus, 26-VI1961, E.J. Fittkau ; seven larvae, Gigante Cr, rapids, Reserva Duke, N of Manaus, 3-4-VII-1961, E.J. Fittkau ; six larvae, 
Passarinho Cr, Roca Antônio, Santo Antônio, $15 \mathrm{~km}$ N of Manaus, 12-XII-1961, E.J. Fittkau ; two larvae, Aracu Cr, 15 km from Manaus, 8-VI-1962, E.J. Fittkau ; larva, Tucuma Rapids, Rio Marauia, NW of Taparuquara, 1-I-1963, E.J. Fittkau ; five larvae, same data as holotype ; 12 larvae, Comeschie Rapids, Rio Marauia, 3 d trip above Santo Antônio Mission, NW of Taparuquara, 28-I-1963, E.J. Fittkau ; larva, Barro Branco Cr, Reserva Duke, N of Manaus, 16-V-1965, E.J. Fittkau. Pará State : Larva, Santarém, Maicá, 27-VI1946, H. Sioli ; larva, Rio Axindéua, 10-XI-1953, H. Sioli ; two larvae, Mulata Cr, 22-IX-1954, H. Sioli ; larva, Bonéku Cr, Tumucumaque Mts, nr Brazil-Suriname border, 14-II1962, W. Sattler ; eight larvae, Akahe Cr, nr Tiriyos Mission, nr Brazil-Suriname border, 15-III-1962, E.J. Fittkau ; six larvae, Okueima Cr, nr Brazil-Suriname border, 18-IV-1962, E.J. Fittkau ; two larvae, Rio Paru, nr Tiriyos Mission, nr Brazil-Suriname border, 31-III-1962, E.J. Fittkau.

\subsubsection{Etymology}

The specific epithet is the Latin word for first. It is in reference to the species being the first described in the genus.

\subsubsection{Discussion}

The presence of long, robust, simple setae on either side of the labrum (Fig. 54), general arrangement of mandibular denticles (Figs. 56, 57), absence of hindwingpads, and irregular paraproctal spination (Fig. 64) may prove to be of diagnostic value at the species level.

\section{Acknowledgments}

We thank R.T. Bonace (Asunción, Paraguay), G.F. Edmunds, Jr. (Salt Lake City, Utah), R.W. Sites (University of Missouri, Columbia), and V. Horeau (Petit Saut, Kourou, French Guyana) for the donation or loan of the material used in this study. We also thank A. Thomas (Toulouse, France) for the French translation of the abstract. This paper has been assigned Purdue Agricultural Research Program Journal No. 15332.

\section{References}

Lewis W.M., Hampton S.K. \& Saunders S.F. 1995. - Rivers in northern South America. Pp. 173-193. In : C.E. Cushing, K.W. Cummins, and G.W. Minshall (eds.), River and stream ecosystems. Elsevier, Amsterdam.
Lugo-Ortiz C.R. \& McCafferty W.P. 1995. - Three distinctive new genera of Baetidae (Insecta, Ephemeroptera) from South America. Annls Limnol., 31 : 233-243.

Lugo-Ortiz C.R. \& McCafferty W.P. 1996a. - Aturbina georgei gen. et sp. n. : a small minnow mayfly (Ephemeroptera : Baetidae) without turbinate eyes. Aq. Insects, $18: 175-183$.

Lugo-Ortiz C.R. \& McCafferty W.P. 1996b. - Phylogeny and classification of the Baetodes complex (Ephemeroptera : Baetidae), with description of a new genus. J. N. Am. benthol. Soc., 15 : 367380 .

Lugo-Ortiz C.R. \& McCafferty W.P. 1996c. - New species of Leptophlebiidae (Ephemeroptera) from Mexico and Central America. Annls Limnol., 32 : 3-18.

Lugo-Ortiz C.R. \& McCafferty W.P. 1996d. - The genus Paracloeodes (Insecta : Ephemeroptera : Baetidae) and its presence in South America. Annls Limnol., 32 : 161-169.

Lugo-Ortiz C.R. \& McCafferty W.P. 1997a. First report and new species of the genus Apobaetis (Epheroptera : Baetidae) from South America. Aq. Insects, in press.

Lugo-Ortiz C.R. \& McCafferty W.P. 1997b. - Taxonomy of the Neotropical Genus Americabaetis, new status (Insecta : Ephemeroptera : Baetidae), Stud. neotrop. Fauna Environ., in press.

McCafferty W.P. 1996. - The Ephemeroptera species of North America and index to their complete nomenclature. Trans. Am. entomol. Soc., $122: 1-54$.

McCafferty W.P. \& Waltz R.D. 1990. - Revisionary synopsis of the Baetidae (Ephemeroptera) of North and Middle America. Trans. Am. entomol. Soc., 116 : 769-799.

McCafferty W.P., Flowers R.W. \& Waltz R.D. 1992. - The biogeography of Mesoamerican mayflies. Pp. 173-193. In : S.P. Darwin and A.L. Welden (eds.), Biogeography of Mesoamerica : proceedings of a symposium, Tulane Univ. Stud. Zool. Bot. Suppl. Publ. 1.

Myers N. 1997. - The rich diversity of biodiversity issues. Pp. 125138. In : M.L. Reaka-Kudla, D.E. Wilson, and E.O. Wilson (eds.), Biodiversity II : understanding and protecting our biological resources. Joseph Henry, Washington, D.C.

Roback S.S. 1966. - The Catherwood Foundation Peruvian-Amazon Expedition. VI. Ephemeroptera nymphs, Monogr. Acad. nat. Sci. Philadelphia. 14 : 129-199.

Traver J.R. \& Edmunds G.F. 1968. - A revision of the Baetidae with spatulate-clawed nymphs (Ephemeroptera). Pac. Insects 10 : 629-677.

Waltz R.D. \& McCafferty W.P. 1985. - Redescription and new lectotype designation for the type species of Pseudocloeon, $P$. kraepelini Klapálek (Ephemeroptera : Baetidae). Proc. entomol. Soc. Wash. 87 : 800-804.

Waltz R.D., McCafferty W.P. \& Thomas A. 1994. - Systematics of Alainites n. gen., Diphetor, Indobaetis, Nigrobaetis n. stat., and Takobia n. stat. (Ephemeroptera, Baetidae). Bull. Soc. Hist. nat. Toulouse, 130 : 33-36. 